
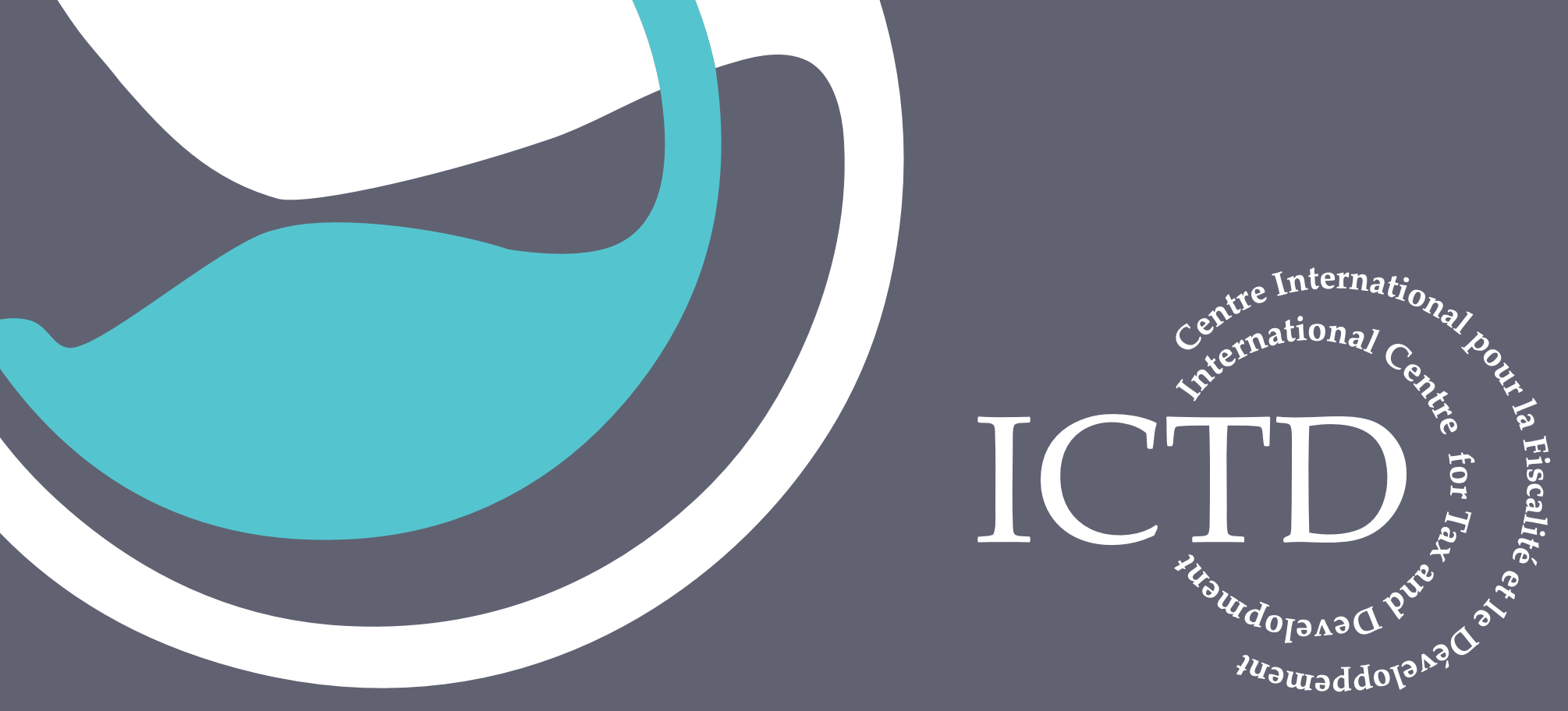

Working Paper 51

\title{
Building Support for Taxation in Developing Countries: Experimental Evidence from Mexico
}

Gustavo A. Flores-Macías

March 2016 
ICTD Working Paper 51

Building Support for Taxation in Developing Countries: Experimental Evidence from Mexico

Gustavo A. Flores-Macías

March 2016 
Building Support for Taxation in Developing Countries: Experimental Evidence from Mexico Gustavo A. Flores-Macías

ICTD Working Paper 51

First published by the Institute of Development Studies in March 2016

(c) Institute of Development Studies 2016

ISBN: 978-1-78118-296-3

A catalogue record for this publication is available from the British Library.

All rights reserved. Reproduction, copy, transmission, or translation of any part of this publication may

be made only under the following conditions:

- with the prior permission of the publisher; or

- with a licence from the Copyright Licensing Agency Ltd., 90 Tottenham Court Road, London W1P 9HE, UK,

or from another national licensing agency; or

- under the terms set out below.

This publication is copyright, but may be reproduced by any method without fee for teaching or nonprofit purposes, but not for resale. Formal permission is required for all such uses, but normally will be granted immediately. For copying in any other circumstances, or for reuse in other publications, or for translation or adaptation, prior written permission must be obtained from the publisher and a fee may be payable.

Available from:

The International Centre for Tax and Development

at the Institute of Development Studies,

Brighton BN1 9RE, UK

Tel: +44 (0) 1273606261 Fax: +44 (0) 1273621202

E-mail: info@ictd.ac.uk

Web: www.ictd/en/publications

IDS is a charitable company limited by guarantee and registered in England (No. 877338) 


\title{
Building Support for Taxation in Developing Countries: Experimental Evidence from Mexico
}

\author{
Gustavo A. Flores-Macías
}

\section{Summary}

In spite of the importance of taxation for political and economic development, we know relatively little about the conditions under which citizens might not exact a political cost on leaders for adopting a particular tax. Drawing on insights from the literature on institutional design, this article examines how certain features of taxes - such as allowing for civil society oversight, sunset provisions that make the duration of taxes finite, and earmark mechanisms that direct tax revenue for a specific purpose - affect political support behind them. It also evaluates the role of three important aspects of the fiscal exchange, namely trust in government, perceptions of the public good, and level of income. Based on an original survey experiment focusing on the provision of public safety in Mexico, I find that these design features increase political support for taxation, especially among those with low trust in government, perceptions of high quality of the public good, and low income. These findings have important implications for Mexico, as well as a number of other countries that have both low levels of extraction and increased public spending imperatives.

Keywords: tax reform; institutional design; public opinion; earmarking; sunsets; oversight; experiment; public safety; developing countries; Mexico.

Gustavo A. Flores-Macías is Assistant Professor in the Government Department and a faculty fellow at the Atkinson Center for a Sustainable Future at Cornell University. He is the author of After Neoliberalism? The Left and Economic Reforms in Latin America (Oxford University Press 2012). His work on political economy has appeared in journals such as American Political Science Review, Comparative Politics, Journal of Conflict Resolution, Journal of Democracy, Journal of Politics, Peace Review, Political Science Quarterly, Studies in Comparative International Development, and as chapters in edited volumes. 


\section{Contents}

Summary 3

Acknowledgements $\quad 5$

Introduction $\quad 6$

$1 \quad$ Public opinion and taxation $\quad 7$

$2 \quad$ Institutional design and political support for taxation 9

$3 \quad$ Research design 12

3.1 Case and public good selection: Mexico's public safety 13

$\begin{array}{lll}3.2 & \text { Experimental conditions } & 14\end{array}$

$4 \quad$ Results $\quad 14$

$\begin{array}{lll}5 & \text { External validity } & 17\end{array}$

6 Conclusion 18

$\begin{array}{ll}\text { Appendices } & 21\end{array}$

$\begin{array}{ll}\text { References } & 24\end{array}$

Figures

Figure 1 Tax-to-GDP ratio by GDP per capita, 2013

Figure $2 \quad$ Average treatment effects compared to baseline 14

$\begin{array}{lll}\text { Figure } 3 & \text { Conditional effects, trust in government } & 15\end{array}$

Figure $4 \quad$ Conditional effects, perception of public good 16

$\begin{array}{lll}\text { Figure } 5 & \text { Conditional effects, income } & 17\end{array}$ 


\section{Acknowledgements}

I would like to acknowledge the International Centre for Tax and Development (ICTD), as well as Richard and Maritza Williamson, for their generosity. I am also grateful to Mick Moore and anonymous reviewers for their comments. 


\section{Introduction}

Taxation lies at the core of several prominent bodies of literature in the social sciences, including those on state capacity, government accountability, economic reform and development. From their insights we know that: taxation is a fundamental source of resources that can translate into state strength (Brautigam et al. 2008; Schneider 2012); taxation results in a link of accountability between citizens and rulers that makes governments more responsive (Paler 2013; Prichard 2015; Tilly 2009); it is conducive to addressing inequality (de Ferranti et al. 2004; Mahon Jr. 2012) and promoting growth (Bird 2012); and, for these reasons, taxation is an essential tool for development (Evans 1995; Huber 2009; Inter-American Development Bank 2013). Not surprisingly, calls by think-tanks (Council of Foreign Relations 2014) and international organisations (Inter-American Development Bank 2013; CAF Banco de Desarrollo de América Latina 2012) for increasing fiscal extraction in the developing world have gained momentum in recent years.

Yet, in spite of this centrality in the academic literature and the policy world, we know relatively little about an important factor behind greater fiscal extraction, namely the determinants of public support behind tax reform, particularly in the developing world. This is because the conventional focus remains on public attitudes towards compliance - that is, reducing evasion (e.g. Cummings et al. 2009; Fjeldstad and Semboja 2001; Torgler 2002, 2005) - rather than the conditions under which the public is more likely to lend political support to fiscal reform. This oversight is consequential, since public support has been found to play an important role in determining the adoption of policies - what scholars refer to as dynamic representation, or the notion that democratic leaders are responsive to the public because their political tenure depends on it (Stimson et al. 1995; Erickson et al. 2002).

This study addresses this lacuna by asking the following questions: What factors affect public support for increased taxation? In particular, does support for taxation respond to different design features of fiscal reform, including variations in modes of oversight, time horizons and expenditure? Are the effects conditional on factors that alter the nature of the fiscal exchange between citizens and government, including levels of trust, perceptions of quality of the public good, and income?

I answer these questions through an original survey carried out in Mexico, a country that ranks among the lowest tax collectors for its level of development (ECLAC 2013), yet has important fiscal demands in the form of security imperatives given its ongoing drug-related public safety concerns. As such, it is well suited to a study of how states can structure fiscal reform in ways that defang, or at least reduce, public opposition. I find that incorporating institutional design features meant to reduce uncertainty in the fiscal exchange into the design of a tax, such as oversight mechanisms, earmarks and sunset provisions, increases political support for increased taxation among the public. The increase in support ranges from 5 to 7 percentage points depending on the design feature. Moreover, I find that these design features are generally most effective given low trust in government, perception of high quality of the public good, and low income.

This novel approach linking institutional design and political support for increased taxation in the developing world breaks new ground in several respects. First, it identifies and draws attention to an important and underdeveloped aspect of the politics of taxation, namely our understanding of the relationship between fiscal reform and public opinion. The literature on the politics of taxation in developing countries has focused on events that are beyond policymakers' control. These include crises, such as economic downturns (Bird 1992; Sanchez 2006), hyperinflation (Mahon Jr. 2004), banking system failure (Hallerberg and Scartascini 2015) and natural disasters (Fairfield 2015); as well as a number of more structural factors affecting governments' ability to tax, including regime type (Cheibub 1998), 
the economy's degree of openness and sectoral configuration (Musgrave 1969; Bahl 1971), class or group-based power (Best 1976; Fairfield 2010, 2015; Flores-Macías 2014; Richter et al. 2009; Timmons 2005), race (Lieberman 2003), ethnicity (Jibao and Prichard 2015), and historical legacies (Ondetti 2012, 2015). The emphasis on crises or structural factors has come at the expense of our understanding of the conditions under which the public is likely to lend political support to fiscal reform. ${ }^{1}$

Second, this study complements the literature on compliance by contributing to our understanding of a step that takes place earlier in time, and before tax obligations are due. While studies of compliance focus on why people cheat on their taxes once tax legislation is adopted, and tend to emphasise expected penalties and the probability of detection (Alm et al. 1992; Slemrod 1992), this study focuses on the determinants of political support regarding the adoption of fiscal reform. While understanding the reasons why people evade taxes has important implications for extraction, it is just as important to consider the relationship between how fiscal policies are designed, and public attitudes on which their adoption and sustainability rest.

Third, this article is the first to explore the role of institutional design features for political support of taxation in the developing world. Insight from institutional design is commonly leveraged in the study of constitutions and electoral rules (Lijphart and Waisman 1996; Negretto 2008; Shugart and Carey 1992), corruption (Rose-Ackerman 1978), central bank reform (Persson and Tabellini 1993) and public service delivery (Jacobs and Matthews 2015), to name a few. This study suggests that design features can also be leveraged to craft more palatable taxes in the eyes of the population, providing a fruitful avenue for future research.

Finally, the article is the first to study the fiscal exchange relationship between taxation and public safety, showing that the link between the two can potentially be leveraged to generate support for fiscal reform. In developing countries where violent crime is on the rise but fiscal extraction is low - as in most of Latin America - this can provide an avenue for policymakers to address these concerns.

The rest of the study proceeds as follows. First, it situates this research in the literature on the importance of public opinion for policymaking in general, and taxation in particular. Next, it discusses theoretical applications as to how institutional design features might reduce uncertainty in the fiscal exchange - and therefore opposition to taxation - and formulates corresponding hypotheses. Third, it discusses the research design, providing details about the experimental protocol as well as context for the public safety scenario. The fourth section presents results, and the fifth discusses external validity. The last section concludes with implications for theory and policy.

\section{Public opinion and taxation}

Stimson et al. (1995) have highlighted the connection between public opinion and policymaking: politicians tend to adjust their ideal policy positions as a function of public opinion, along with other factors, in order to get closer to an expediency point - where they believe they do not jeopardise their chances of re-election. This process shapes policy decisions by rational anticipation (Stimson et al. 1995), and can potentially shape electoral outcomes if the public's views are not heeded. This does not mean that mass public opinion is the only important factor, or more important than the views of, or pressure exerted by, elites. Rather, this suggests that, without public support for a policy, politicians will have a

An exception is Fairfield (2013), which suggests strategies for governments to increase tax revenue. However, its emphasis is on economic elites rather than political support among the general public. 
harder time advancing their agenda: legislators face electoral disincentives to go against their constituents, and executives will have trouble garnering legislative majorities.

The question is whether this logic extends to all policies, or whether some areas of public policy are more removed from public attitudes than others. One camp suggests that public opinion does not matter for the adoption of tax policy; instead, distributive battles are waged among elites, and voters are not relevant in the process (Alesina and Drazen 1991). This perspective would point to the expansion of the tax base in Latin America through regressive Value Added Tax (VAT) over the last thirty years as evidence that voters are not relevant in determining tax policy, given that this policy favours economic elites at the expense of the bulk of the population. The same could be said about Europe, where corporate taxes have been reduced and consumption taxes have gone up, neither of which would appear to be in the interest of most survey respondents.

A competing and more persuasive perspective suggests that even the best policies fail in the absence of the right political conditions to make them amenable to the public and sustainable over time (Haggard and Webb 1994; Haggard and Kaufman 1995; Armijo and Faucher 2002). With an emphasis on structural reform during the 1980s and 1990s, a large literature points to the importance of support among the population as a key factor for the political realisation of economic transformation in Africa, Eastern Europe and Latin America (Baker 2003, 2009; Bratton et al. 2004; Buendía 1996; Johnson and Kowalska 1994; Przeworski 1996; Stokes 1996, 2001; Weyland 1998).

On tax policy in particular, scholars have observed that tax reform is closely related to legislative battles over the distributional consequences of policies (de Ferranti et al. 2004), and public attitudes play a significant role in determining whether an additional tax burden is adopted, at least in a democracy (Fjeldstad el al. 2012). This is the case because of the electoral recourse of citizens whenever they deem the tax burden excessive or unfair. Disenchanted citizens can express their discontent at the ballot box, which makes office holders receptive to the views of the population (Stimson et al. 1995). Unless the public is willing, leaders increase extraction at their peril - which compromises the government's ability to increase the provision of quality public goods. Ideally, then, they would generate revenue under conditions of public support.

Although elites naturally play an important role in outlining the tax policy agenda, there is evidence that public opinion also plays a role in shaping tax reform: office holders both seek information about the public's attitudes, and tend to act accordingly. For example, experimental research in the United States has shown that legislators who are aware of their constituents' views through public opinion surveys tend to vote in line with those views (Butler and Nickerson 2011). In Chile, the Piñera administration relied on public opinion polls to evaluate whether to raise taxes on corporations in 2010 (Fairfield 2015: 266). In Mexico, Presidents Ernesto Zedillo (1994-2000) and Felipe Calderón (2006-2012) commissioned surveys in 1999 and 2012 to evaluate the support behind proposed tax measures (Casar 2013).

There is also evidence that policymakers act on this information by advancing, altering or withholding altogether fiscal reform because of public opinion. Cases in point are reforms whose political success or failure has hinged on the public's views, regardless of whether the outcome might translate into good public policy or benefit its supporters. In the United States, for instance, although the 2001 and 2003 Bush tax cuts generated a 'massive upward transfer of wealth' from the poor to the rich, they were adopted because of the broad support the measure enjoyed among the ordinary Americans who would least benefit from it (Bartels 2005: 16). Similarly, generalised public support largely contributed to repealing the estate tax, even though it only affected the wealthiest 1 or 2 per cent of taxpayers (Bartels 2005). In Colombia, legislators of the Liberal Party pointed to the public's opposition to increasing VAT 
as the main justification for blocking the measure in Congress and supporting other types of taxes instead (Flores-Macías 2014). In Mexico, the administrations of Vicente Fox (20002006) and Felipe Calderón pushed for increases in VAT revenue, but public opposition derailed these governments' plans in 2001 and 2007, and watered them down considerably in 2009. More recently, Enrique Peña Nieto's (2012-present) government intended to adopt VAT for food, medicine, tuition and mortgages in 2013, but decided to pull the measure in the face of 70 per cent disapproval (CNN Mexico 2013; Romero 2015). ${ }^{2}$

To be sure, governments might still carry out unpopular reforms, but not without a political cost. Executives and legislators investigate public attitudes through both commissioned and publicly-available surveys, make reference to them when making appeals to support or oppose fiscal reform, and act on this information by adjusting their behaviour - whether tailoring tax initiatives accordingly or informing their vote. Given the high stakes characteristic of fiscal reform, re-election-minded politicians have every incentive to pay attention to the public's views on initiatives that might become politically toxic. The more popular reforms are, the more political cover policymakers will enjoy when adopting them.

\section{Institutional design and political support for taxation}

Against the backdrop of political elites being attentive to public attitudes about tax policy, the question arises as to whether particular tax structures are more or less likely to attract public support. In other words, to what extent does institutional design - the creation of 'rules and incentives [...] to achieve substantive goals' (Weimer 1985: 8) - affect individual attitudes by creating incentives or disincentives to offer support (Olsen 1997)? In the context of constitutional design, for example, scholars have found that particular rules are important in preserving democracy by giving relevant parties a stake in the system (Lijphart and Waisman 1996; Shugart and Carey 1992), and electoral rule design has been found to shape the strength and number of parties in the system (Negretto 2008; Powell 1989). Similarly, the field of behavioural economics has pointed to the importance of choice architecture - or how the way choices are presented can influence people's decisions (Thaler and Sunstein 2009). Research evaluating the consequences of specific institutional features, holding other things equal, has focused on corruption (Rose-Ackerman 1978), the political control of administrative agencies (McCubbins et al. 1989), the economic consequences of the independence of central banks (Persson and Tabellini 1993), and the effects of budgetary rules on deficits (von Hagen 1992).

There are different ways in which institutional design features contribute to reducing the incentives to oppose a policy initiative. In particular, institutional design might help to reduce the asymmetries between principal and agents - such as citizens and governments - or reduce the inter-temporal uncertainty involved in bearing the costs today for the promise of uncertain rewards in the future. Among the main strategies to achieve these objectives is to incorporate transparency or diligence requirements, automating policy decisions, and restricting the agenda to make commitments credible (Weimer 1985, 1992).

Transparency or diligence requirements help to reduce the uncertainty that an agent might not be fulfilling a task consistent with the interest of the principal (Weimer 1985). Such requirements are common in attempts to reduce government officials' discretion, or prevent them from engaging in illegal behaviour, such as corruption. Examples range from the 
requirement that certain rules be visible at all times as a reminder of desirable behaviour or outcomes, to the formation of oversight committees in charge of monitoring activities.

Automating policy decisions helps to reduce uncertainty about future outcomes by reducing discretion (Rodrik and Zechhauser 1988). Such design features are meant to bring clarity to the policy process, since the steps in a sequence of events is predetermined. Examples range from tying a programme's eligibility requirements to an established criterion (e.g. the poverty line determines eligibility for Food Stamp programmes), to incorporating an explicit end to the duration of a policy to allow for its re-evaluation (e.g. adopting sunset provisions) (Weimer 1992).

Restricting the policy agenda also contributes to reducing uncertainty (Rodrik and Zechhauser 1988). These provisions can tie governments' hands to prevent future changes in leadership, ideology, or priorities altering agreements reached today. The most common example is to guarantee that revenue is necessarily channelled to a particular programme what is often referred to as earmarking. In short, institutional design features can reduce uncertainty by addressing discretion of government officials in the policymaking process that might threaten the benefits envisioned by the population.

As in the other fields of study mentioned above, these institutional design strategies might play a role in ameliorating the misalignment of incentives between re-election-minded office holders pushing for reform, and a public opposed to bearing a greater fiscal burden today for the promise of public goods in the future. In particular, design features that enhance credibility, shorten time horizons in case the policy is misguided, and restrict the agenda could reduce uncertainty and increase political support for fiscal reform today.

First, regarding transparency and diligence requirements, taxpayers' ability to follow how resources are spent has been associated with greater willingness to pay taxes (Elster 1989; OECD 2008; Prichard 2010; Scholz and Lubell 1998). Although governments tend to have oversight mechanisms - auditors, legislative committees and comptrollers, among others to monitor the performance and financial probity of other agencies, in developing countries these efforts are often considered insufficient and in need of complementary citizens' action to oversee government activity (Goetz and Jenkins 2001).

To reduce the uncertainty that tax revenue might be embezzled, wasted, or spent inappropriately, non-governmental or civil society oversight can add a layer of credibility to assuage these concerns. Examples of civil society oversight range from 'people's audits' of local government expenditure by non-governmental organisations (NGOs) in India (Goetz and Jenkins 2001), to NGO groups analysing security budgets in Argentina (UNDP 2008), to prominent members of civil society, such as university presidents and business leaders, monitoring how tax revenue from a wealth tax is spent in El Salvador (Flores-Macías 2015).

Second, regarding automating policy decisions, sunset provisions can reduce uncertainty about the fiscal exchange by shortening the time horizon of the tax burden. Although not without detractors, who blame sunset provisions for biasing policymaking towards the status quo at the expense of meaningful change (Rhee Baum and Bawn 2011; Viswanathan 2007: 672), sunset provisions stand to increase political support for taxation. Since they force legislatures to reevaluate the consequences of their actions after a period of time and allow for the possibility of adjustment (Deran 1965), short-lived taxes can provide hope that the additional burden will be brief. For example, Fairfield (2015), suggests that an automatic sunset provision included in a tax reform package was instrumental in reducing the opposition of business elites to President Sebastian Piñera's fiscal reform package. Similarly, Flores-Macías (2014) points to a three-year sunset clause facilitating the adoption of wealth taxes in Colombia since 2002. 
Third, the restriction of the policy agenda as a strategy to reduce taxpayers' uncertainty can be achieved through earmarking - that is, establishing a clear link between tax revenue and expenditure (Bahiigwa et al. 2004). Although detractors point to their rigidity over time (McCleary and Uribe Tobon 1990), and governments' failure to allocate resources according to earmarks in practice (McCleary 1991), earmarked taxes can protect social priorities from budget crunches and political fluctuations (Eklund 1969). Earmarks are likely to be more popular among the public because they allow for a policy outcome that might be closer to individuals' preferences (Buchanan 1963; Fairfield 2013). In the developing world, where weak institutions are a concern, earmarking tax revenue can provide taxpayers some level of assurance that funds will be used for their intended purpose. As Teja (1988: 531) has pointed out, earmarking can 'substitute for lack of representative power in the executive and legislative branches of government'. In Latin America, countries such as Colombia, Costa Rica and Honduras have also earmarked specific taxes for the purposes of public safety (Flores-Macías 2015).

Thus, building on insight from the literature on institutional design, three hypotheses follow about the relationship between the structure of a proposed tax policy and public support for that proposal.

$\mathrm{H} 1$ : Support for additional taxation will increase when an oversight mechanism is incorporated into the design of the tax.

H2: Support for additional taxation will increase when a sunset provision is incorporated into the design of the tax.

H3: Support for additional taxation will increase when the tax revenue is explicitly earmarked as part of the design of the tax.

\section{Heterogeneous effects: trust, quality of the public good, and income}

While these institutional design features might help to address uncertainty that future benefits might not materialise after bearing the fiscal burden today, their effect is likely to vary among certain groups of the population. First, the literature on taxation suggests that trust in government is important for fiscal extraction (Slemrod 2002). In developing countries with a history of government corruption, as in Latin America, the public tends to be especially sceptical about their taxes being spent as intended. Whether individuals trust the government or not is likely to shape whether the three institutional design features discussed earlier are able to increase political support for a greater tax burden. Less trusting individuals are likely to be more cynical about the potential benefits of greater taxation (Bergman 2002; Fjeldstad and Semboja 2001; Prichard 2010). Because of their mistrust in government, they may not consider these design features realistic or meaningful. People who mistrust the government might believe these mechanisms are a sham, and that they will not ultimately enjoy the benefits. Therefore, their views are likely to be less affected by the three institutional design mechanisms - monitoring, earmarks and sunset provisions - given that their success requires confidence that the government will actually execute the measures.

A second factor potentially affecting support for increased taxation is people's perception of the public good provided by the government. As Levi (1988), Timmons (2005) and others have argued, there is an expectation that comes with handing over part of one's wealth to the government. When individuals perceive their taxes to be at work, they may feel they are getting a fair fiscal exchange (Fjeldstad and Semboja 2001; Lledo et al. 2004; Moore 2004, 2008). Accordingly, government effectiveness in spending taxpayers' resources to achieve stated goals has been associated with citizens' support for taxation (OECD 2008). It follows that the level of satisfaction with the fiscal exchange will contribute to determining people's support for increased taxation. Individuals feeling shortchanged in the exchange will likely be less supportive of increases in the tax burden. 
A third area of heterogeneity to be considered is the level of income. State-society relations in the developing world tend to be especially asymmetric among low-income groups compared to their wealthier counterparts, because wealthier sectors enjoy more leverage to influence policy outcomes (Fairfield 2015). Wealthier groups have better resources to both shape tax policymaking and to find ways to reduce their tax obligation once policy has been set, whereas low-income sectors tend to be less empowered to demand benefits in exchange for their taxes. Therefore, institutional design features might have a greater effect on reducing uncertainty in the fiscal exchange among lower-income sectors.

Given these potential differences in the terms of the fiscal exchange based on trust, perception of the public good and income, a second set of hypotheses follows:

H4: The effect of the three institutional design features on support for increased taxation will be lower among people who mistrust the government.

H5: The effect of the three institutional design features on support for increased taxation will be lower among people who perceive low quality in the provision of the public good.

H6: The effect of the three institutional design features on support for increased taxation will be lower among wealthier sectors.

\section{Research design}

I evaluate these hypotheses in the context of a survey experiment conducted in Mexico. Experiments allow researchers to vary certain treatment conditions that may not be possible to observe simultaneously in a particular context - for example, one cannot observe individuals' support for taxes with and without certain tax rules at the same time. Additionally, when properly randomised, they allow researchers to attribute causal effects to the experimental manipulations and determine the magnitude of these effects (Druckman et al. 2006). This design allows us to transcend correlations-based research that has characterised public opinion studies, while responding to the call for research on the key determinants of tax attitudes in developing countries (Fjeldstad et al. 2012). The findings allow us to determine which design factors are causally relevant in shaping attitudes towards increased taxation, the size of their effect, and whether effects are conditional on features relevant to the fiscal exchange.

An established polling firm - Data Opinión Pública y Mercados, which has experience conducting surveys among nationally-representative samples in Mexico - conducted the experimental survey. The survey experiment was conducted through face-to-face interactions at the respondents' home, drawn from a nationally representative probabilitybased random sample of 1,300 respondents. Contrary to the use of online or telephone surveys, frequent in developed countries because of the generalised availability of these services, survey research among a representative sample in developing countries often requires face-to-face interactions at the respondents' home. Because of the oral nature of the survey, the experimental treatments were kept relatively brief and straightforward.

Randomisation of treatments took place independently of the sampling process, and the likelihood of being assigned to a particular treatment was the same for all respondents in a sampling unit. ${ }^{3}$ Consequently, there is little concern for high intra-class correlation coefficients. A table showing descriptive statistics for each treatment condition is shown in the Appendix.

A computer randomised the version of the questionnaire assigned to each respondent. Respondents were drawn from Mexico's national voting registry. 


\subsection{Case and public good selection: Mexico's public safety}

Mexico's low levels of taxation make this country a useful case to test these hypotheses. With one of the lowest tax-to-GDP ratios (11 per cent) among middle-income countries, Mexicans historically have borne a low tax burden compared to its potential (ECLAC 2013). As Figure 1 shows, Mexico has one of the largest gaps between the expected fiscal extraction for its level of income (solid line in Figure 1) and its actual extraction. The country's natural resource wealth - which generates a third of government revenue - has provided an alternative to taxation, making it harder to justify tax increases. Not surprisingly, when asked about the existing tax burden, 58 per cent of Mexicans say it is too high, 27 per cent about right, and 4 per cent too low - this is comparable to views in the United States, which has a strong anti-taxation tradition. Thus, Mexico is a case where the public is used to paying a low tax burden, making changes in public support more difficult, but which - as with most of Latin America - stands to benefit considerably from increased fiscal revenue.

\section{Figure 1 Tax-to-GDP ratio by GDP per capita, 2013}

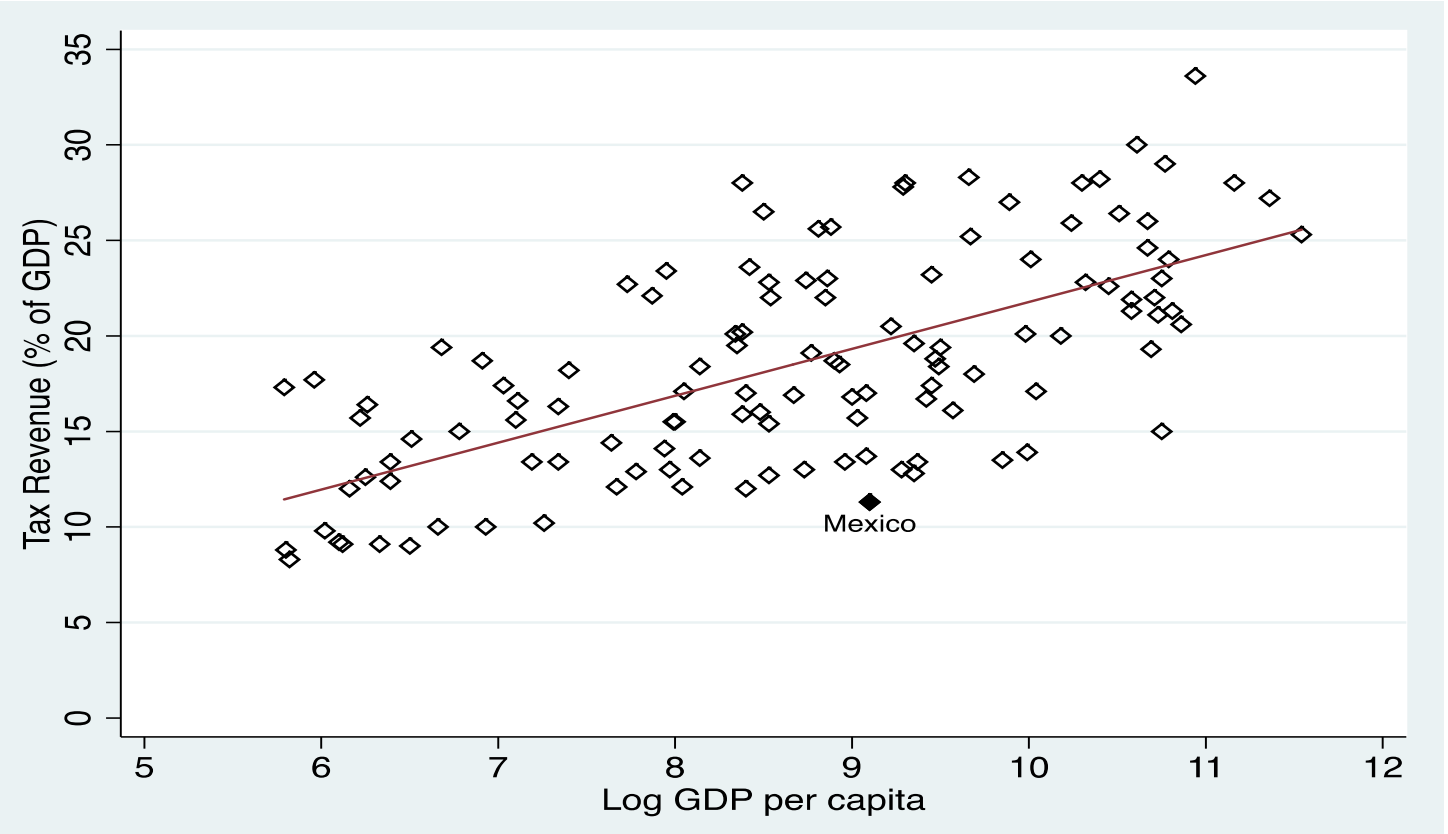

Source: IMF Government Finance Statistics and World Bank World Development Indicators Online.

I selected security as a concrete public good in which to ground the experiment, both because of its importance in the hierarchy of public goods and because of its salience in Mexico and the rest of Latin America. Although there tends to be considerable disagreement, often related to ideological positions, as to what constitutes the core functions of the state that is, whether the state should be involved in providing such services as health care and education, and to what extent - there is a consensus regarding the centrality of public safety as one of the state's main functions (Tilly 2009). Without public safety, other important functions, such as allowing markets to function, cannot be even minimally performed.

Further, security is considered to be the main problem facing Mexico. More than 42 per cent of respondents in a survey discussed below mentioned security-related issues, such as public safety, drug trafficking and crime, with public safety as the most common response (27 per cent). In contrast, 22 per cent pointed to the economy as the main problem, and 17 per cent to unemployment. Of those responding an economic issue as the main ailment, about half recorded public safety as the second main problem for the country. This concern for public safety as the main problem facing the country is not atypical: it is consistent with the views in a majority of countries in Latin America (Latinobarometer 2013). 


\subsection{Experimental conditions}

In the experiment, respondents were randomly assigned to one of four groups - three treatments and a control - to test hypotheses corresponding to the three tax design factors associated with individual support for taxation: a) oversight, b) sunset and c) earmark provisions. The control group was told that, in light of recent debates about public safety, some experts recommended increasing public safety expenditure, and that one proposal to do so was to raise taxes. Respondents were then asked: with this proposal in mind, to what extent would you support paying more in taxes than you currently do. Treatment groups were given the same information, but were asked the extent to which they would support paying more in taxes than they currently do if: a committee of respected civil society members oversaw how the tax revenue were spent / the new taxes disappeared in 3 years and Congress was forced to debate them again / the additional tax revenue was used exclusively for public safety.

Along with the experimental treatments, other items in the survey allow us to evaluate heterogeneous effects. Respondents were asked about their trust in the government, perceptions of public safety in their community, and their income. The full text of the questions is included in the Appendix.

\section{Results}

The experiment's results support the hypotheses that these institutional design features can indeed generate political support for taxation. Net support - those who changed their views from opposition to support - increased from a baseline of about 17 per cent in the control group to about 22 per cent with civil society oversight $(\mathrm{H} 1), 24$ per cent for a sunset provision $(\mathrm{H} 2)$, and 24 per cent with earmarking $(\mathrm{H} 3)$. Thus, these design features increased support by between 6 and 7 points, depending on the treatment (Figure 2). In relative terms, this represents an increase of between 31 and 38 per cent with respect to the 17 percentage point baseline of support. The treatment involving civil society oversight appears to enjoy slightly lower levels of support compared to including a sunset provision or earmarking, but estimates of change in support for the three design features fall roughly within the same confidence interval and cannot be differentiated statistically.

Figure 2 Average treatment effects compared to baseline

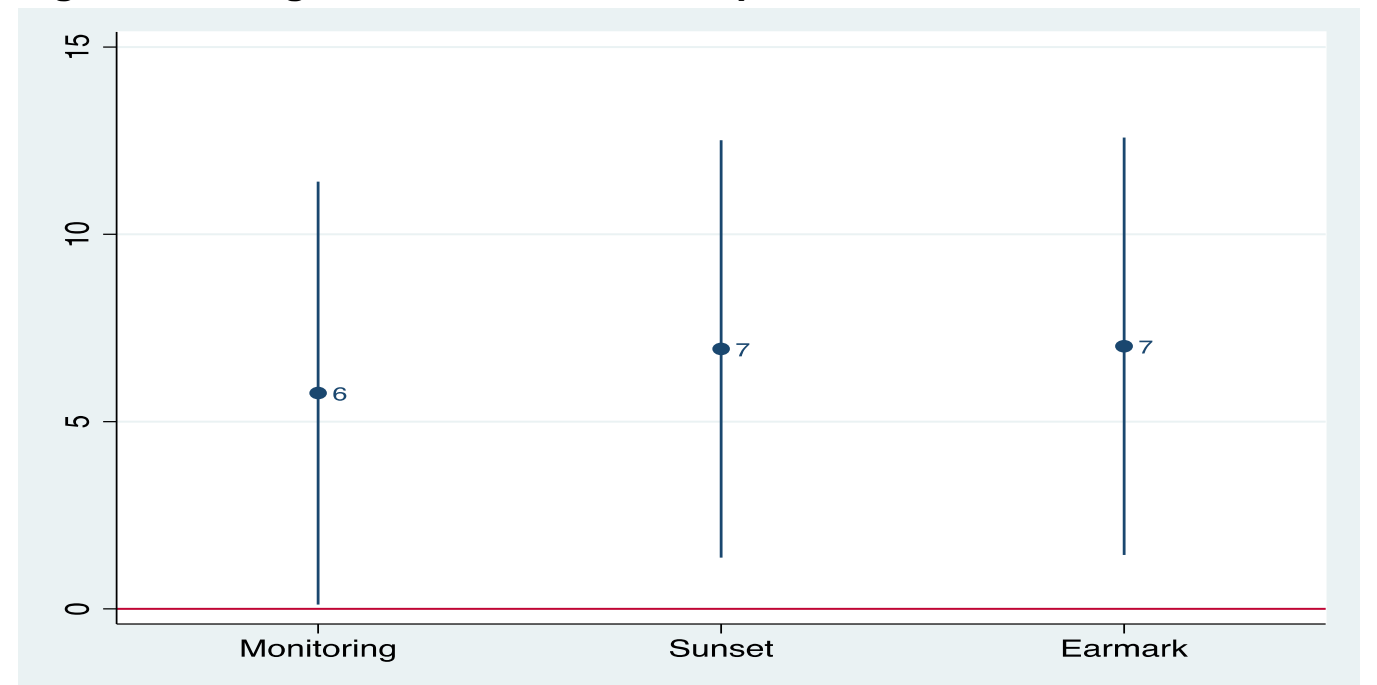

NB: Circles represent estimates for the treatment effects. Vertical lines represent $95 \%$ confidence intervals. Tests are one-tailed because of the direction of the hypotheses. 
To put these magnitudes in perspective, whereas only 4 per cent of the population expresses support for increased taxation when asked whether the tax burden should increase in the abstract - a share comparable to that in the United States - support reached 17 per cent once increased taxation was discussed in the context of public safety. This support further increased to up to 24 per cent when specific design features were mentioned. Support for taxation was slightly higher when earmarks and sunset provisions were included as part of the architecture of the tax, compared to monitoring by civil society groups, although the difference between treatments was not large enough to be statistically significant. Given that the scenario presented to all respondents was related to public safety, the 7-point effect of earmarking might be understated and therefore represent a lower bound.

Regarding conditional effects, the results do not support the hypothesis $(\mathrm{H} 4)$ that the effect of the institutional design will be lower among respondents reporting low levels of trust in the government. Instead, they provide some suggestive evidence to the contrary. ${ }^{4}$ Whereas the effect of the treatments is small and decidedly not significant among the high trust group, among the low trust group the effect of earmarks is large (13 points) and significant, and the effect of sunsets is large (9 points) and barely missing significance (Figure 3 ). The effect of monitoring is not significant in either group, but the estimate is twice as large in the low trust group. This suggests that the design features might be especially effective in reducing uncertainty among those who are most sceptical of the government.

\section{Figure 3 Conditional effects, trust in government}

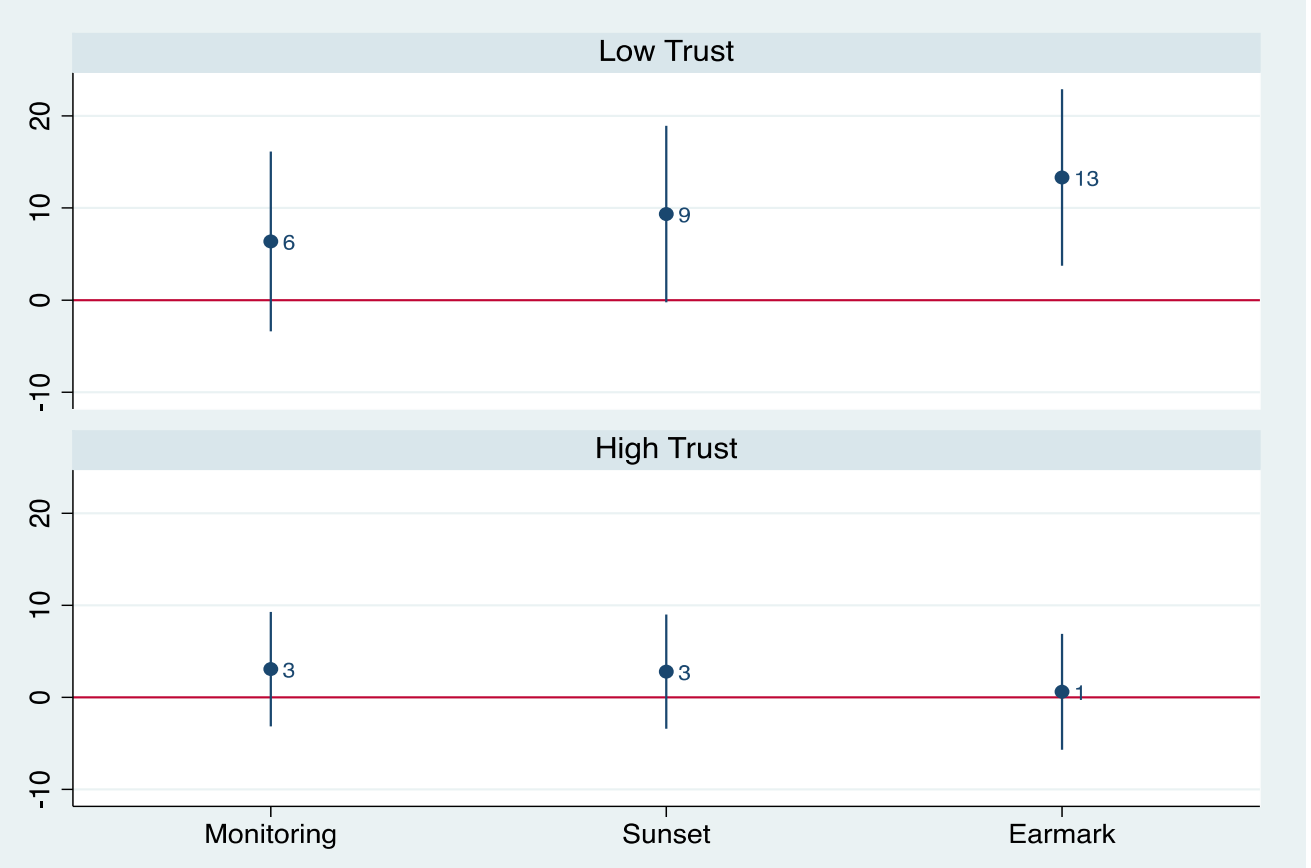

NB: Circles represent estimates for the treatment effects. Vertical lines represent $95 \%$ confidence intervals. Tests are one-tailed because of the direction of the hypotheses.

The results lend evidence to support the hypothesis $(\mathrm{H} 5)$ that the effect of the institutional design features will be lower among those who perceive the public good provision to be deficient. ${ }^{5}$ Whereas no institutional design feature reached significance among those who perceive their community to be unsafe, the effect was greater among those who expressed

\footnotetext{
$4 \quad$ In order to evaluate this hypothesis, those who expressed they had little or no trust in government were grouped in the low trust category, whereas those who expressed some or a lot of trust in government were grouped in the high trust category.

5 Respondents who expressed feeling very unsafe or somewhat unsafe in their community formed the unsafe group, whereas those who expressed feeling very safe or somewhat safe formed the safe group.
} 
their community to be safe, and significant for the civil society oversight and earmark treatments - the sunset treatment barely missed significance (Figure 4). This suggests that those who perceive they have benefited from the provision of the public good - in this case public safety - are more responsive to the influence of institutional design features as a means to increase support for additional taxes.

Figure 4 Conditional effects, perception of public good

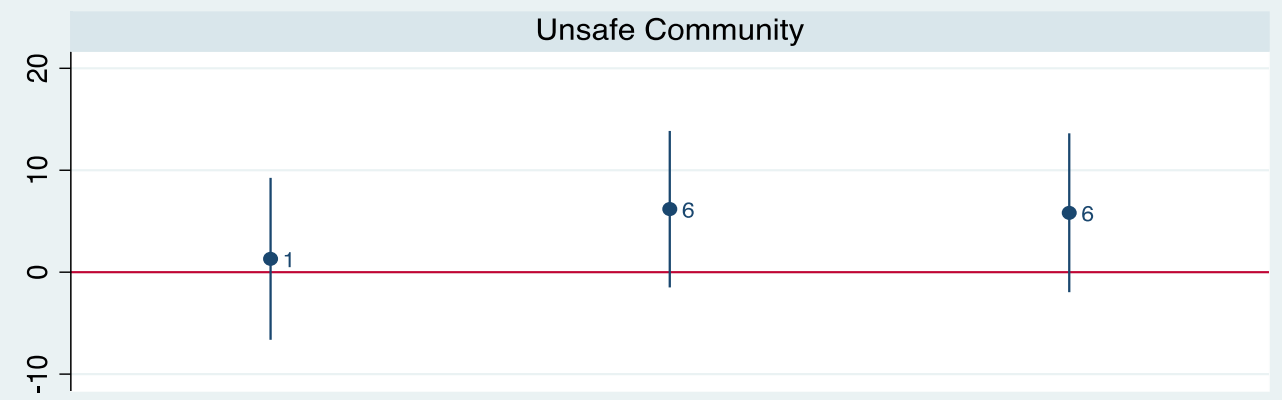

Safe Community

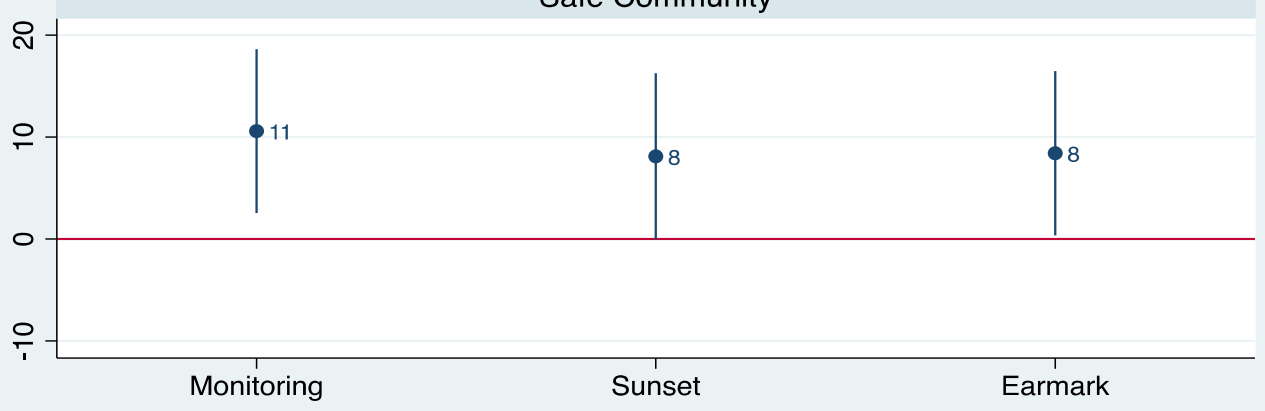

NB: Circles represent estimates for the treatment effects. Vertical lines represent $95 \%$ confidence intervals. Tests are one-tailed because of the direction of the hypotheses.

Finally, the results provide some support for the hypothesis $(\mathrm{H} 6)$ that the effect of the institutional design features will be lower among wealthier sectors. ${ }^{6}$ Whereas no treatment is significant among the wealthy, among the lower-income group the effects of sunset and earmark provisions were large - 11 and 10 points, respectively - and significant (Figure 5). These results suggest that those who are less empowered to demand benefits in exchange for their taxes are more responsive to the uncertainty-reducing institutional design features. 
Figure 5 Conditional effects, income

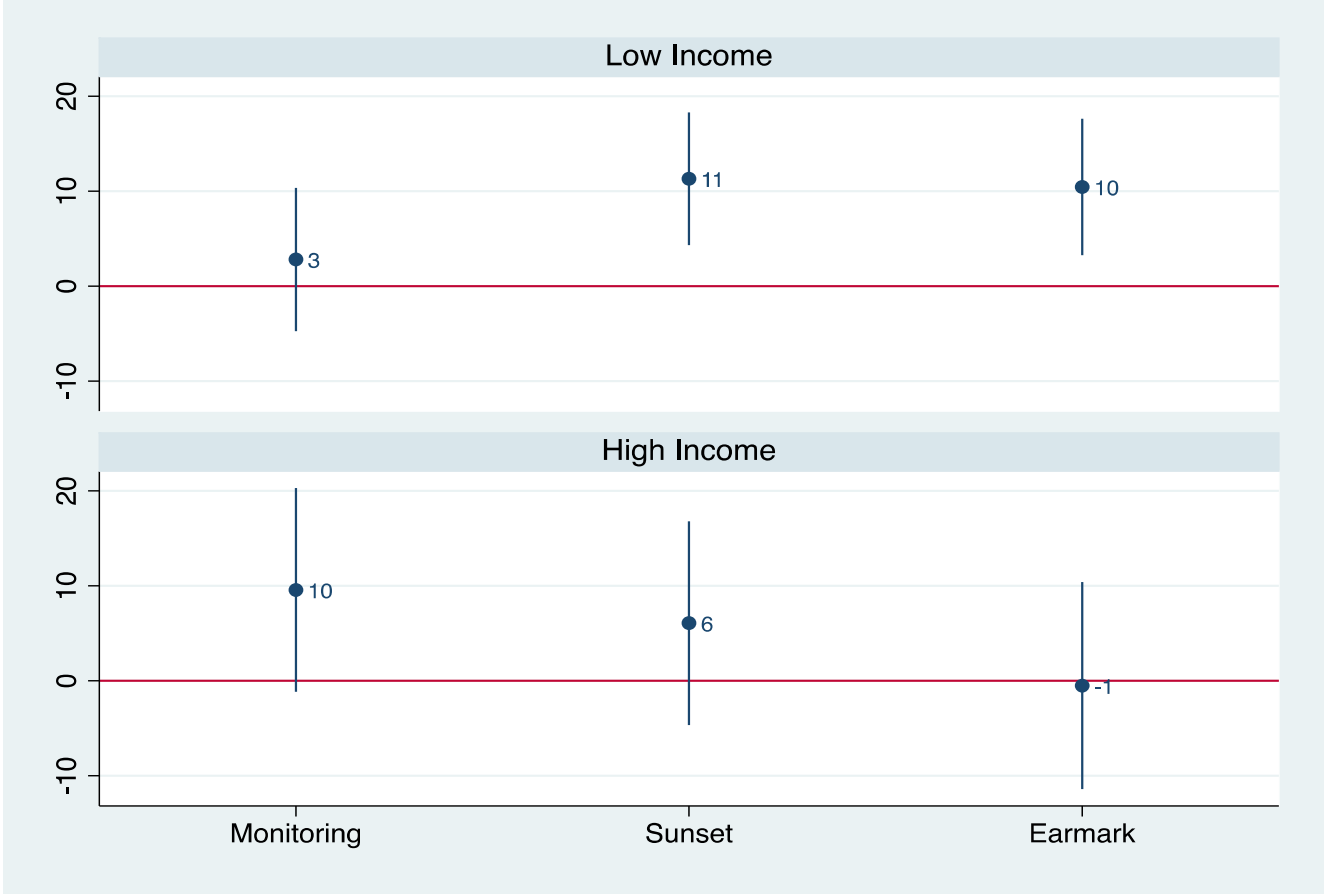

NB: Circles represent estimates for the treatment effects. Vertical lines represent $95 \%$ confidence intervals. Tests are one-tailed because of the direction of the hypotheses.

Overall, earmark provisions had a significant effect given groups with low trust, favourable perceptions of public safety, and lower income. Sunset provisions were similar, except that they barely missed significance among the groups with low trust and perceptions of a safe community. Civil society monitoring was only significant among the group with favourable perceptions of the public good.

\section{External validity}

Although experimental research provides many advantages for inference, one of the main pitfalls associated with it is the lack of external validity (Druckman et al. 2006). This study is externally valid in the following ways. First, by surveying respondents through a nationally representative, probability-based sample, there is greater confidence that results are reflective of the attitudes of the population in the entire country - as opposed to unrepresentative convenience samples - both for levels of support, as well as the magnitudes of the average treatment effects.

Second, several features provide ecological validity - that is, how closely the experiment approximates reality. The experiment draws on a realistic scenario that is of importance for the public, and has already materialised in several Latin American countries. Not only has public safety become the main public concern in most Latin American countries in recent years, but also taxes related to public safety have recently been adopted or discussed in several countries, including Colombia, Costa Rica, El Salvador, Guatemala and Honduras. The specifics of the three treatments - an oversight committee of respected civil society, a three-year sunset period, and earmarking for public safety - are drawn from actual examples in these countries. That more countries increasingly face these challenges suggests the findings are relevant not just for Mexico, but across the developing world. 
Further, the exercise resembles what takes place when a fiscal reform is considered: polling firms ask citizens about their views on a series of proposed measures, and citizens in turn express their support or opposition. These surveys take place prospectively - that is, before the measure is adopted - to determine how much political support the measures might enjoy. Contrary to experiments on compliance, the actual payment of taxes does not have to be involved in order to approximate reality, since political support for a measure is not expressed on the day taxes are due, but around the time the measure is proposed and debated. ${ }^{7}$ In fact, a person might support a tax and therefore contribute to making it politically palatable, regardless of whether the person fulfills her tax obligations down the road or whether she is even affected by the tax. In short, although actual taxes are not at stake in the experiment, the situation resembles the type of survey that governments and legislatures employ to evaluate the degree of political support a measure enjoys.

Additionally, because of the questionnaire constraints involved in face-to-face interviews where respondents cannot take their time to read an experimental treatment at their leisure as in online surveys - the experimental treatments were very subtle. That the treatments were able to move public support in spite of this suggests that these effects might be understated compared to the stronger exposure to the different design features that is likely to take place in reality. These institutional designs could very well have a greater effect in ameliorating the public's concerns when the stakes are higher with an actual reform.

Finally, this study does not allow us to determine whether these effects hold for other types of goods. It might very well be that public safety is unique, and people are less willing to pay for public education or healthcare. However, because of the importance of public safety for publics across the region and the tall order in the hierarchy of public goods provided by the state, the study of public safety makes a valuable contribution as a first step towards understanding political support for other types of goods.

\section{Conclusion}

Contrary to the traditional focus on crises, structural factors or compliance, this study shifted the emphasis for the study of tax reform in the developing world towards the public opinion underpinnings of political support for tax reform. Consistent with research that has shown that making economic reform politically palatable can be a difficult proposition (Murillo 2001; Weyland 1998), animosity towards greater extraction tends to run high regardless of the setting - Mexico is no exception. However, the findings presented here suggest that this animosity is not fixed. Instead, relatively simple design features of a tax can make a difference for making reform more palatable to the public - although by themselves they are not enough to generate overwhelming support, if there is ever such a thing for taxation.

In addition to suggesting that the public is likely to respond favourably to measures that reduce the uncertainty inherent in prospective economic reform through provisions related to oversight, sunset and earmark mechanisms, the findings also speak to the effect of the distributional consequences of taxation, highlighting the groups for which institutional design features are most effective in generating political support for tax reform. In particular, the result that those with low levels of trust in the government were especially affected by sunset and earmarking provisions runs counter to the expectation that they would be the most cynical about the prospect of bearing a greater fiscal burden (Slemrod 2002). That these provisions were also most effective among the lower-income group, suggests that they could

For example, it is not difficult to imagine a real-life scenario in which a person is supportive of a tax when it is first debated and adopted, but has changed her mind when taxes are due. The first one has to do with political support for the adoption of reforms - the focus of this study - whereas the second is related to compliance. 
potentially become a way to empower those sectors. The findings also lend support to the view that perceptions of a fair fiscal exchange matter (Fjeldstad and Semboja 2001; Lledo et al. 2004; Moore 2004, 2008), even for a relatively abstract public good such as public safety.

These results should open the door to further research based on insights from institutional design and behavioural economics in order to make fiscal reform politically palatable. As institutional design features reduce uncertainty about the benefits associated with fiscal reform, taxation will become more appealing to the public and increasing fiscal resources will become less threatening to elected officials.

Indeed, as public safety has become one of the public's main concerns across the developing world (Afrobarometer 2013; Latinobarometer 2013), many governments have struggled to find the fiscal resources necessary to fund increasingly demanding security efforts while maintaining prevailing levels of spending in other areas. In particular, low levels of taxation in many developing countries have impaired governments' ability to invest in alleviating poverty, improving security forces and administering justice, all of which are crucial for the provision of public safety in particular, and the strengthening of the state more generally.

As in Mexico, many other countries in the region are faced with the dual challenge of low fiscal extraction and deteriorating public safety. On the one hand, there is an increasing realisation of the importance of second-generation reform (Naim 1994; Pastor and Wise 1999), taxation being one of the most prominent (Huber 2009). On the other, the region is the most violent in the world, and public safety is the main or second most important concern in Argentina, Bolivia, Brazil, Colombia, Costa Rica, Chile, Ecuador, El Salvador, Guatemala, Honduras, Mexico, Nicaragua, Paraguay, Peru, Uruguay and Venezuela (Latinobarometer 2013). Although the results here rely on a public safety scenario and may not apply to other goods, they are suggestive of an avenue to extract additional revenue. Future work should evaluate whether these findings apply to other types of public goods, and whether combinations of these institutional design features might have an additive effect.

The findings presented here suggest that the determinants of political support for increased taxation might not necessarily be the same as those of tax compliance. In particular, although perceptions of quality of the public good (Alm et al. 1992) and trust in government (Fauvelle-Aymar 1999) seem to play a role in both cases, other factors point in different directions. For example, whereas compliance research has found that how income is generated is important but not the level of income (Kirchler et al. 2008; Park and Hyun 2003), the level of income did play a role in shaping the effect of institutional design treatments on public support for increased taxation.

These findings should be read with two caveats in mind. First, understanding the specific context of countries matters. In particular, the fiscal consequences of different types of design features should be taken into consideration. Earmarking as a way to increase public support behind taxation, and in turn generate political support, may be appropriate in some settings, but sunset provisions may be appropriate for others. ${ }^{8}$ Given the inability to extract adequate levels of resources from society in many developing countries, the disadvantages of these design features should be weighed against the advantages of reducing resistance to fiscal extraction.

Second, the findings should not be interpreted as suggesting that increased taxation is the only or most important goal in the abstract. Efforts to make public spending more effective

For example, some governments face legal impediments for earmarking. However, some have found ways to circumvent constitutional restrictions by adopting de facto earmarks, as with President Alvaro Uribe's wealth taxes in Colombia. 
are equally important for good governance, and should be made a priority as well. Rather, the insights presented here regarding the effects of the three design features of taxes on public support for taxation should contribute to expanding the political toolkit aimed at strengthening the fiscal sphere of the state in the developing world. 


\section{Appendices}

\section{Appendix 1 Experimental treatments}

You may have heard discussions about public safety in Mexico. Some experts suggest increasing spending in public safety, including in policing, the judicial system and crime prevention.

One proposal to achieve this is to collect more in taxes.

\section{[Insert treatment here]}

\section{Treatments}

\section{Baseline}

With this proposal in mind, to what extent would you support paying more in taxes than you currently do?

\section{Oversight}

With this proposal in mind, to what extent would you support paying more in taxes than you currently do, if a committee of respected civil society members oversaw how the tax revenue was spent?

\section{Sunset}

With this proposal in mind, to what extent would you support paying more in taxes than you currently do, if the new taxes disappeared in three years and Congress was forced to debate them again?

\section{Earmark}

With this proposal in mind, to what extent would you support paying more in taxes than you currently do, if the additional tax revenue was used exclusively for public safety? 
Appendix 2 Randomisation check: Means across treatments and one-way Anova

\begin{tabular}{l|c|c|c|c|c}
\hline \hline Variable & Control & Monitoring & Earmark & Sunset & $\begin{array}{c}\text { One-way Anova (p } \\
\text { value) }\end{array}$ \\
\hline Age & 41.2 & 40.8 & 40.6 & 40.8 & 0.97 \\
\hline Education & 9.0 & 8.8 & 9.1 & 8.8 & 0.73 \\
\hline Female & 0.48 & 0.52 & 0.52 & 0.47 & 0.42 \\
\hline Income & 3.1 & 3.0 & 3.1 & 3.0 & 0.66 \\
\hline Perception safety & 2.5 & 2.5 & 2.5 & 2.5 & 0.47 \\
\hline Tax burden & 2.6 & 2.6 & 2.5 & 2.6 & 0.37 \\
\hline Trust & 2.2 & 2.4 & 2.3 & 2.4 & 0.07 \\
\hline Urban & 0.24 & 0.28 & 0.26 & 0.24 & 0.55 \\
\hline \hline
\end{tabular}

\section{Appendix 3 Summary statistics}

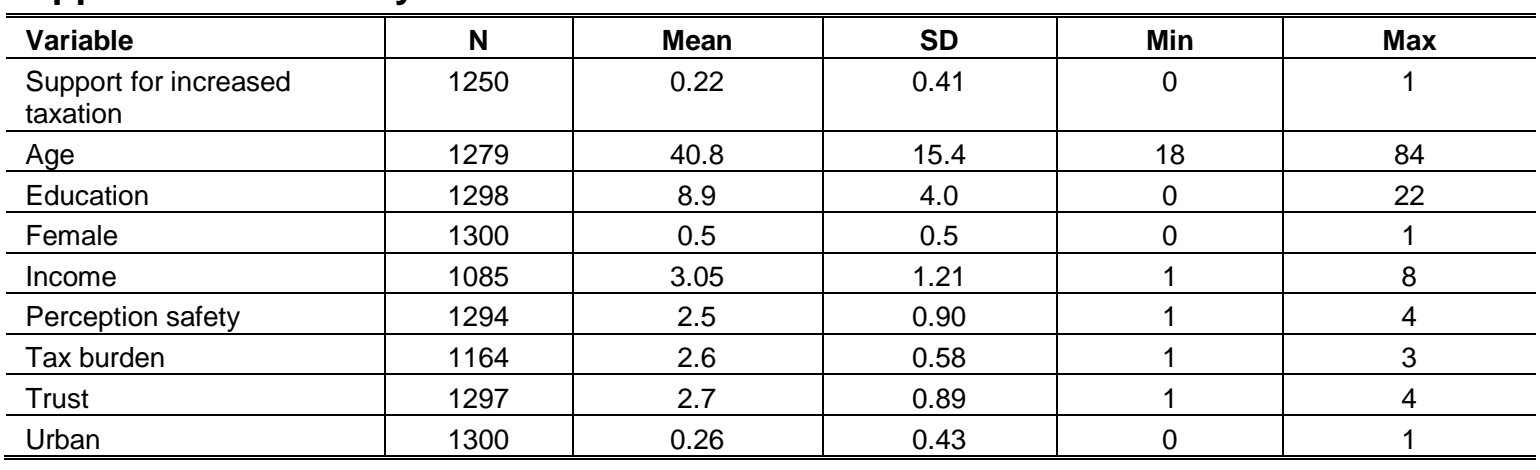

\section{Appendix 4 Results for Figures 2, 3, 4, and 5}

\section{Average treatment effects}

\begin{tabular}{|c|c|}
\hline \multicolumn{2}{|c|}{ Level of support } \\
\hline Experimental condition & $(\%)$ \\
\hline Control & 17 \\
\hline Monitoring & 23 \\
\hline Earmark & 24 \\
\hline Sunset & 24 \\
\hline \multicolumn{2}{|c|}{ Effects from difference in Means Test and $95 \% \mathrm{Cl}$} \\
\hline Monitoring & $\begin{array}{c}6 \\
(0.1 \text { to } 11) \\
\end{array}$ \\
\hline Earmark & $\begin{array}{c}7 \\
\text { (1 to 12) } \\
\end{array}$ \\
\hline Sunset & $\begin{array}{c}7 \\
\text { (1 to } 12) \\
\end{array}$ \\
\hline
\end{tabular}

NB: Tests are one-tailed because of the direction of the hypotheses. 
Conditional effects, trust in government

\begin{tabular}{|c|c|c|}
\hline \multicolumn{3}{|c|}{ Level of support (\%) } \\
\hline Experimental condition & Low trust & High trust \\
\hline Control & 24 & 13 \\
\hline Monitoring & 30 & 16 \\
\hline Earmark & 37 & 14 \\
\hline Sunset & 33 & 16 \\
\hline \multicolumn{3}{|c|}{ Effects from difference in Means Test and $95 \% \mathrm{Cl}$} \\
\hline Monitoring & $\begin{array}{c}6 \\
(-3 \text { to } 15) \\
\end{array}$ & $\begin{array}{c}3 \\
(-3 \text { to } 9) \\
\end{array}$ \\
\hline Earmark & $\begin{array}{c}13 \\
\text { (4 to } 23) \\
\end{array}$ & $\begin{array}{c}1 \\
(-5 \text { to } 6) \\
\end{array}$ \\
\hline Sunset & $\begin{array}{c}9 \\
(-0.3 \text { to } 18)\end{array}$ & $\begin{array}{c}3 \\
(-4 \text { to } 9)\end{array}$ \\
\hline
\end{tabular}

NB: Tests are one-tailed because of the direction of the hypotheses.

Conditional effects, perceptions of public good

\begin{tabular}{|c|c|c|}
\hline \multicolumn{3}{|c|}{ Level of support (\%) } \\
\hline Experimental condition & Unsafe community & Safe community \\
\hline Control & 20 & 14 \\
\hline Monitoring & 21 & 24 \\
\hline Earmark & 26 & 22 \\
\hline Sunset & 26 & 21 \\
\hline \multicolumn{3}{|c|}{ Effects from difference in Means Test and $95 \% \mathrm{Cl}$} \\
\hline Monitoring & $\begin{array}{c}1 \\
(9 \text { to } 6) \\
\end{array}$ & $\begin{array}{c}10 \\
\text { (2 to } 18)\end{array}$ \\
\hline Earmark & $\begin{array}{c}6 \\
(-2 \text { to } 13)\end{array}$ & $\begin{array}{c}8 \\
(0.3 \text { to } 15)\end{array}$ \\
\hline Sunset & $\begin{array}{c}6 \\
(-2 \text { to } 14) \\
\end{array}$ & $\begin{array}{c}7 \\
(-0.05 \text { to } 15) \\
\end{array}$ \\
\hline
\end{tabular}

NB: Tests are one-tailed because of the direction of the hypotheses.

\section{Conditional effects, income}

\begin{tabular}{|c|c|c|}
\hline \multicolumn{3}{|c|}{ Level of support (\%) } \\
\hline Experimental conditions & Low income & High income \\
\hline Control & 11 & 26 \\
\hline Monitoring & 13 & 36 \\
\hline Earmark & 21 & 26 \\
\hline Sunset & 22 & 21 \\
\hline \multicolumn{3}{|c|}{ Effects from difference in Means Test and $95 \% \mathrm{Cl}$} \\
\hline Monitoring & $\begin{array}{c}2 \\
(-4 \text { to } 8)\end{array}$ & $\begin{array}{c}10 \\
(-1 \text { to } 21)\end{array}$ \\
\hline Earmark & $\begin{array}{c}10 \\
(3 \text { to } 17)\end{array}$ & $\begin{array}{c}0 \\
(-10 \text { to } 10)\end{array}$ \\
\hline Sunset & $\begin{array}{c}11 \\
\text { (4 to } 18) \\
\end{array}$ & $\begin{array}{c}6 \\
(-5 \text { to } 17) \\
\end{array}$ \\
\hline
\end{tabular}

NB: Tests are one-tailed because of the direction of the hypotheses. 


\section{References}

Afrobarometer (2013) Online Data Analysis, May

Aguirre, J. (2011) Construcción de la ciudadanía, Reporte CESOP 50 (November)

Alesina, A. and Drazen, A. (1991) 'Why Are Stabilizations Delayed?', American Economic Review 81(5): 1170-1188

Alm, J., Jackson, B. and McKee, M. (1992) 'Institutional Uncertainty and Taxpayer Compliance', American Economic Review 82(4): 1018-1026

_ McClelland, G. and Schulze, W. (1992) 'Why Do People Pay Taxes?', Journal of Public Economics 48: 21-38

Armijo, L. and Faucher, P. (2002) 'We Have A Consensus: Explaining Political Support for Market Reforms in Latin America', Latin American Politics and Society 44(2): 1-40

Bahiigwa, G., Ellis, F., Fjeldstad, O-H. and Iversen, V. (2004) Rural taxation in Uganda: Implications for growth, income distribution, local government revenue and poverty reduction, EPRC Research Series No. 35 (January), Kampala: Economic Policy Research Centre

Bahl, R. (1971) A Regression Approach to Tax Effort and Tax Ratio Analysis, Staff Papers, International Monetary Fund 18(3): 570-612

Baker, A. (2009) The Market and the Masses in Latin America: Policy Reform and Consumption in Liberalizing Economies, New York: Cambridge University Press

_ (2003) 'Why Is Trade Reform so Popular in Latin America? A Consumption-Based Theory of Trade Policy Preferences', World Politics 55: 3

Bartels, L. (2005) 'Homer Gets a Tax Cut: Inequality and Public Policy in the American Mind,' Perspectives on Politics 3(1): 15-31

Bergman, M. (2002) 'Who Pays for Social Policy? A Study on Taxes and Trust', Journal of Social Policy 31(2): 289-305

Best, M. (1976) 'Political Power and Tax Revenues in Central America', Journal of Development Economics 3(1): 49-82

Bird, R. (2012) Taxation and Development: What Have We Learned from Fifty Years of Research?, ICTD Working Paper 1, Brighton: ICTD

_ (1992) 'Tax Reform in Latin America: A Review of Some Recent Experiences', Latin American Research Review 27: 1

Bratton, M., Mattes, R. and Gymah-Boadi, E. (2004) Public Opinion, Democracy, and Market Reform in Africa, New York: Cambridge University Press

Brautigam, D., Fjeldstad, O-H. and Moore, M. (eds) (2008) Taxation and State-Building in Developing Countries, New York: Cambridge University Press 
Buchanan, J. (1963) 'The Economics of Earmarked Taxes', Journal of Political Economy 71 : 457-69

Buendía, J. (1996) 'Economic Reform, Public Opinion, and Presidential Approval in Mexico', Comparative Political Studies 29(5): 566-591

Butler, D. and Nickerson, D. (2011) 'Can Learning Constituency Opinion Affect How Legislators Vote? Results from a Field Experiment', Quarterly Journal of Political Science 6: 55-83

CAF Banco de Desarrollo de América Latina (2012) Finanzas públicas para el desarrollo: fortaleciendo la conexión entre ingresos y gastos, Bogotá: Panamericana Formas e Impresos

Casar, M.A. (2013) 'Los mexicanos contra los impuestos', Revista Nexos, 1 November 2012

Cheibub, J. (1998) 'Political Regimes and Extractive Capacity of Governments: Taxation in Democracies and Dictatorships', World Politics 50(3): 349-376

CNN Mexico (2013) 'La Comisión de Hacienda aprueba reforma sin IVA a colegiaturas y rentas', 17 October 2013

Council of Foreign Relations (2014) 'Mexico's Oil and Taxes', Latin America's Moment Blog

Cummings, R., Martinez-Vazquez, J. McKee, M. and Torgler, R. (2009) 'Tax Morale Affects Tax Compliance: Evidence from Surveys and an Artefactual Field Experiment', Journal of Economic Behavior and Organization 70(3)

De Ferranti, D., Perry, G., Ferreira, F. and Walton, M. (2004) Inequality in Latin America: Breaking with History?, Washington DC: The World Bank

Deran, E. (1965) 'Earmarking and Expenditures: A Survey and a New Test', National Tax Journal 18: 354-61

Druckman, J., Green, D., Kuklinski, J. and Lupic, A. (2006) 'The Growth and Development of Experimental Research in Political Science', American Political Science Review 100(4): 627-637

ECLAC (2013) Fiscal Panorama of Latin America and the Caribbean, Santiago, Chile: Economic Commission for Latin America and the Caribbean

Eklund, P. (1969) Taxation and Earmarking in Developing Countries, World Bank Staff Working Paper 43, Washington DC: World Bank

Elster, J. (1989) 'Social Norms and Economic Theory', Journal of Economic Perspectives $3(1)$

Erickson, R., Mackuen, M., and Stimson, J. (2002) The Macro Polity, New York NY: Cambridge University Press

Evans, P. (1995) Embedded Autonomy: States and Industrial Transformation, Princeton NJ: Princeton University Press

Fairfield, T. (2015) Private Wealth and Public Revenue in Latin America, New York: Cambridge University Press 
_ (2013) 'Going Where the Money Is: Strategies for Taxing Economic Elites in Unequal Democracies', World Development 47: 42-57

_ (2010) 'Business Power and Tax Reform', Latin American Politics and Society 52(2): $51-71$

Fauvelle-Aymar, C. (1999) 'The Political and Tax Capacity of Governments in Developing Countries', Kyklos 52(3): 391-413

Fjeldstad, O-H., Schulz-Herzenberg, C. and Hoem Sjursen, I. (2012) People's Views of Taxation in Africa: A Review of Research on Determinants of Tax Compliance, CMI Working Paper 2012/7 and ICTD Working Paper 8

and Semboja, J. (2001) 'Why People Pay Taxes: The Case of the Development Levy in Tanzania', World Development 29: 2059-2074

Flores-Macías, G. (2015) 'Fortalecimiento del Estado en Latinoamérica: seguridad pública e impuestos', Foreign Affairs Latinoamérica 15(4): 64-69

- (2014) 'Financing Security through Elite Taxation: The Case of Colombia's Democratic Security Taxes', Studies in Comparative International Development 49(4): 477-500

Goetz, A-M. and Jenkins, R. (2001) 'Hybrid Forms of Accountability: Citizen Engagement in Institutions of Public Sector Oversight in India', Public Management Review 3(3): 363383

Haggard, S. and Kaufman, R. (1995) The Political Economy of Democratic Transitions. Princeton, NJ: Princeton University Press

__ and Webb, S. (eds) (1994) Voting for Reform, New York: Oxford University Press

Hallerberg, M. and Scartascini, C. (2015) 'When Do Governments Improve Fiscal Institutions? Lessons from Financial Crisis and Fiscal Reform in Latin America', Economia 16(1): 41-76

Huber, E. (2009) 'Politics and Inequality in Latin America', PS: Political Science and Politics 42(2): 651-655

Inter-American Development Bank (2013) More than Revenue: Taxation as a Development Tool, Washington DC: IDB

Jacobs, A. and Matthews, S. (2015) 'Policy Attitudes in Institutional Context: Rules, Uncertainty, and the Mass Politics of Public Investment', American Journal of Political Science, Online First

Jibao, S. and Prichard, W. (2015) 'The Political Economy of Property Tax in Africa: Explaining Reform Outcomes in Sierra Leone', African Affairs 114(456): 404-431

Johnson, S. and Kowalska, M. (1994) 'Poland: The Political Economy of Shock Therapy', in S. Haggard and S. Webb (eds), Voting for Reform, Washington DC: The World Bank

Kirchler, E., Hoelzl, E. and Wahl, I. (2008) 'Enforced vs. Voluntary Tax Compliance: The Slippery Slope Framework', Journal of Economic Psychology 29(2): 210-225 
Latinobarometer (2013) Online Data Analysis

Levi, M. (1988) Of Rule and Revenue, University of California Press

Lieberman, E. (2003) Race and Regionalism in the Politics of Taxation in Brazil and South Africa, New York: Cambridge University Press

Lijphart, A. and Waisman, C. (1996) Institutional Design in New Democracies: Eastern Europe and Latin America, Westview Press

Lledo, V., Schneider, A. and Moore, M. (2004) Pro-poor Tax Reform in Latin America: A Critical Survey and Policy Recommendations, IDS Working Paper 221

Mahon Jr., J. (2012) Tax Incidence and Tax Reforms in Latin America, Washington DC: Wilson Center

_ (2004) 'Causes of Tax Reform in Latin America, 1977-95', Latin American Research Review 39:1

McCleary, W. (1991) 'The Earmarking of Government Revenue: A Review of Some World Bank Experience', World Bank Observer 6(1): 81-104

and Uribe Tobon, E. (1990) Earmarking Government Revenues in Colombia, PRE Working Paper WPS 425, Washington DC: World Bank

McCubbins, M., Noll, R., and Weingast, B. (1989) 'Structure and Process, Politics and Policy: Administrative Arrangements and the Political Control of Agencies,' Virginia Law Review 75(2): 431-482

Moore, M. (2008) 'Between Coercion and Contract: Competing Narratives around Taxation and Governance', in D. Brautigam, O_H. Fjeldstad and M. Moore (eds) Taxation and State Building in Developing Countries: Capacity and Consent, Cambridge: Cambridge University Press

- (2004) 'Revenues, State Formation, and the Quality of Governance in Developing Countries'. International Political Science Review, 25: 297-319

Murillo, M. (2001) Labor Unions, Partisan Coalitions, and Market Reforms in Latin America, New York: Cambridge University Press

Musgrave, R. (1969) Fiscal Systems, Yale University Press

Naim, M. (1994) 'Latin America: The Second Stage of Reform', Journal of Democracy 5(4): $32-48$

Negretto, G. (2008) 'Political Parties and Institutional Design: Explaining Constitutional Choice in Latin America', British Journal of Political Science 39: 117-139

OECD (2008) Governance, Taxation, and Accountability: Issues and Practices, Paris: OECD Development Assistance Committee

Olsen, J. (1997) 'Institutional Design in Democratic Contexts', Journal of Political Philosophy 5(3): 202-229 
Ondetti, G. (2015) 'The Roots of Brazil's Heavy Taxation', Journal of Latin American Studies 47(4): 749-779

- (2012) Tax Burdens and Historical Legacies in Brazil and Mexico, paper presented at the annual meeting of the American Political Science Association in New Orleans

Paler, L. (2013) 'Keeping the Public Purse: An Experiment in Windfalls, Taxes, and the Incentives to Restrain Government', American Political Science Review 107(4): 706725

Park, C-G. and Hyun, J. (2003) 'Examining the Determinants of Tax Compliance by Experimental Data: The Case of Korea', Journal of Policy Modeling 25(8): 673-684

Pastor, M. and Wise, C. (1999) 'The Politics of Second Generation Reform', Journal of Democracy 10(3): 34-48

Persson, T. and Tabellini, G. (1993) 'Designing Institutions for Monetary Stability', CarnegieRochester Conference Series on Public Policy 39(1): 53-84

Powell, B. (1989) 'Constitutional Design and Citizen Electoral Control', Journal of Theoretical Politics, 1(2): 107-130

Prichard, W. (2015) Taxation, Accountability, and Responsiveness in Sub-Saharan Africa: The Dynamics of Tax Bargaining, Cambridge University Press

_ (2010) Taxation and State Building: Towards a Governance Focused Tax Reform Agenda, IDS Working Paper 341, Brighton: Institute of Development Studies

Przeworski, A. (1996) 'Public Support for Economic Reforms in Poland', Comparative Political Studies 29(5)

Rhee Baum, J. and Bawn, K. (2011) 'Slowing at Sunset: Administrative Procedures and the Pace of Reform in Korea', Journal of East Asian Studies 11(2): 197-221

Richter, B, Samphantharak, K. and Timmons, J. (2009) 'Lobbying and Taxes', American Journal of Political Science 53(4): 893-909

Richupan, S. (1987) 'Determinants of Income Tax Evasion', in P. Ghandi (ed) Supply-side Tax Policy: Its Relevance to Developing Countries, Washington DC: IMF

Rodrik, D. and Zeckhauser, R. (1988) 'The Dilemma of Government Responsiveness', Journal of Policy Analysis and Management 7(4): 601-620

Romero, V. (2015) 'The Political Economy of Progressive Tax Reforms in Mexico', in J. Mahon Jr., M. Bergman, and C. Arnson (eds) Progressive Tax Reform and Equality in Latin America, Washington DC: Woodrow Wilson Center

Rose-Ackerman, S. (1978) Corruption: A Study in Political Economy, New York: Academic Press

Sánchez, O. (2006) 'Tax System Reform in Latin America: Domestic and International Causes', Review of International Political Economy 13(5): 772-801

Schneider, A. (2012) State Building and Tax Regimes in Central America, New York: CUP 
Scholz, J. and Lubell, M. (1998) 'Trust and Taxpaying: Testing the Heuristic Approach to Collective Action', American Journal of Political Science 42(2): 398-417

Shugart, M. and Carey, J. (1992) Presidents and Assemblies: Constitutional Design and Electoral Dynamic,. New York: Cambridge University Press

Slemrod, J. (2002) Trust in Public Finance, NBER Working Paper 9187

_ (ed) (1992) Why People Pay Taxes: Tax Compliance and Evasion, Ann Arbor: University of Michigan Press

Stimson, J., Mackuen, M. and Erikson, R. (1995) 'Dynamic Representation', American Political Science Review 89(3): 543-565

Stokes, S. (2001) Public Support for Market Reforms in New Democracies, New York: Cambridge University Press

_ (1996) 'Economic Reform and Public Opinion in Peru, 1990-1995', Comparative Political Studies 29(5)

Teja, R. (1988) 'The Case for Earmarked Taxes', IMF Staff Papers 35(3): 523-533

Thaler, R. and Sunstein, C. (2009) The Nudge, Penguin Books

Tilly, C. (2009) 'Introduction', in I. Martin, A. Mehrotra and M. Prasad (eds), The New Fiscal Sociology: Taxation in Comparative and Historical Perspective, New York NY: Cambridge University Press

Timmons, J. (2005) 'The Fiscal Contract: States, Taxes, and Public Services', World Politics 57(4): 530-567

Torgler, B. (2005) 'Tax Morale in Latin America', Public Choice 122(1/2): 133-157

- (2002) 'Speaking to Theorists and Searching for Facts: Tax Morale and Tax Compliance in Experiments', Journal of Economic Surveys 16(5): 657-683

UNDP (2008) Public Oversight o the Security Sector: A Handbook for Civil Society Organizations, United Nations Development Programme

Viswanathan, M. (2007) 'Sunset Provisions in the Tax Code: A Critical Evaluation and Prescriptions for the Future', NYU Law Review 82: 656-688

Von Hagen, J. (1992) 'Budgeting Procedures and Fiscal Performance in the European Communities', Commission of the European Communities Economic Papers 96 (October): 1-85

Weimer, D. (1992) 'Claiming Races, Broiler Contracts, Heresthetics, and Habits: Then Concepts for Policy Design', Policy Sciences 25: 135-159

— (1985) 'Institutional Design: Overview', in D. Weimer (ed) Institutional Design, Norwell MA: Kluwer Academic Press

Weyland, K. (1998) 'Swallowing the Bitter Pill: Sources of Popular Support for Neoliberal Reform in Latin America', Comparative Political Studies 31:5: 539-568 


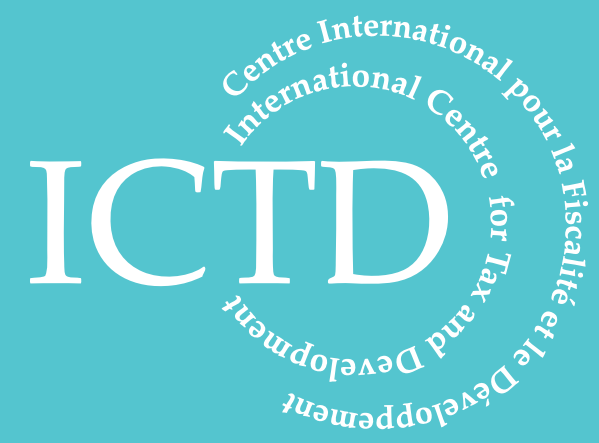

International Centre for Tax and Development at the Institute of Development Studies

Brighton BN1 9RE, UK

T: +44 (0) 1273606261

F: $+44(0) 1273621202$

E: info@ictd.ac

www.ictd.ac 